\title{
Comparative analysis of trends in the export of higher education in Russia and Poland
}

\author{
Aleksandr A. Gusakov ${ }^{1}$, Vita Jukneviciene ${ }^{2}$ \\ ${ }^{I}$ Peoples' Friendship University of Russia (RUDN University), Moscow, Russia \\ ${ }^{2}$ Institute of Regional Development, Šiauliai Academy, Vilnius University, Šiauliai, Lithuania \\ *Email: gusakov-aa@rudn.ru
}

\begin{abstract}
The article analyses the main trends in the development of higher education exports in Russia and Poland. For this purpose, data from the official statistics of both countries, OECD, have been collected and analysed. A list of countries from which the flow of students to both countries is increasing has been determined. An analysis is made of whether the number of students in Russia from the CIS countries depends on the ruble exchange rate fluctuations. To identify the motivation of international students when choosing a country of study, a survey of students from 18 countries studying at RUDN University was conducted. This university is the most international in the Russian Federation; students from 160 countries learn there. The survey results are compared with a similar survey that was conducted in 2012, as well as with a survey previously conducted at the Technical University of Opole. The main problems international students face in Russia and Poland have been identified. The economic reasons for the desire of both countries to increase the number of international students are formulated.
\end{abstract}

Keywords: Export of education, Student migration, International students in Poland, International students in Russia.

\section{INTRODUCTION}

The export of education creates additional income for universities, attracts talented youth and creates other consumer demand in the territory. One of the key indicators of this activity is the number of international students. The OECD keeps statistics on the mobility of international students. Interstate associations and supranational structures, such as the European Union and the CIS, create conditions for more unrestricted flows of human capital between countries, including the migration of students to higher education in another country. Many developed countries have strategic programs to develop higher education exports [1]. The Russian Federation (hereinafter referred to as Russia) and the Republic of Poland (hereinafter referred to as Poland) were selected as the object of analysis. Polish and Russian diasporas are located in different countries of the world. Both countries are part of the post-Soviet space, so they were similar at the time of transition to a new formation. However, there are also significant differences in the transition processes.
The general trend for Poland and Russia in recent years is depopulation. The purpose of analysing trends in student migration is to identify both general trends and significant differences and determine factors. According to the OECD definition, the export of educational services includes providing educational services to international students in person or through modern communication technologies. The concept of "student migration" implies studying in another country to obtain a qualification (diploma of higher education), that is, long-term mobility.

\section{METHODOLOGY}

In this study, desk studies and surveys were used as a method of data collection. To analyse the trends of student migration in Russia and Poland, we used data on international students reflected in the official statistical reports of these countries. The study also analysed publications and reports of other authors and organisations on student migration, including the 
surveys' results of international students studying at universities in Poland and Russia. In the autumn semester of the 2020-2021 academic year, a survey of international students studying at the RUDN was conducted. 84 students from 18 countries took part in the survey. The purpose of the study was to identify the motives for coming to Russia for education. Since students from more than 160 countries study at RUDN, a survey of students even at one university with a broad international composition allows us to identify trends.

\section{RESULTS AND DISCUSSION}

\subsection{Trends of student migration to Russia and Poland}

Globalisation contributes to forming new trends in the labour and education markets. When choosing a future profession, young people consider the possibility of studying in another country as a factor that will allow them to get a high-paying job in a country with a high level of social security. Every year the flow of international students is growing, which will mean a higher internationalisation of future employees [2]. A few rationales drive high education internationalisation: political, economic, academic, and sociocultural [3]. In recent years, the number of international students in Russia has continued to grow. The total number of foreign citizens who studied in the 2018-2019 academic year at Russian universities in all forms of education amounted to 353.3 thousand people, including 213.5 thousand full-time university students (bachelors, specialities, masters) [4]. The total number of international students in the 2018-2019 academic year at universities in Poland was 78.3 thousand people [5]. This amounted to $8.54 \%$ of the total number of students in Russia and $6.37 \%$ in Poland.

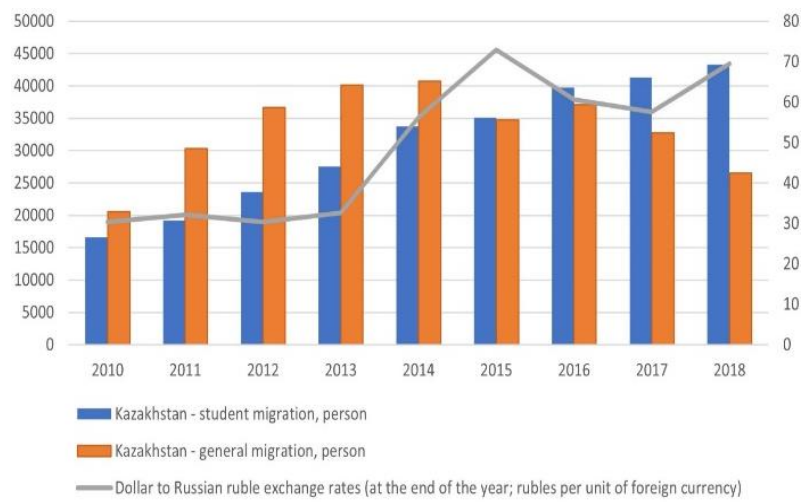

Figure 1 General and student migration from Kazakhstan to Russia.

Compiled by the authors based on [4], [11]

Foreign citizens have the right to receive education in Russia following international agreements and the legislation of Russia. To attract students from other countries to Russian universities, the federal authorities have approved a quota for international students to study at universities at the expense of the Russian federal budget. These international students receive a scholarship and a place in a hostel. In 2008, this quota was equal to 10 thousand people per year, 2021 - 18 thousand people, and starting from 2023 - 30 thousand people [6]. Higher education is one of the areas of cooperation between Russia and neighbouring countries within the framework of the CIS and the SCO (Shanghai Cooperation Organization).

Currently, Russia is in seventh place globally regarding the number of international students [4]. The total revenues from the export of Russian educational services in the 2018/2019 academic year amounted to USD 2,270.2 million, with less than $30 \%$ of this amount actually being paid for training, and the rest - living expenses, meals, transport, leisure, etc. while living in Russia. The number of fee-based international students in Russia has grown [4]. The possibility of such economic benefits has led to a shift in focus from a political benefit to a purely economic point of view - as a source of nonoil exports. To achieve the new economic goals, the federal authorities, at the end of 2017, approved the Priority project "Export of Russian Education" [7]. The implementation of this project should increase the attractiveness of Russian educational programs for foreign citizens, improve the conditions of their stay while studying in Russia, and increase the awareness of the "brand" of Russian education. The goal is to increase the number of international students to 425 thousand people. It is essential to provide employment opportunities for university graduates in the country of study.

According to the 'Government Program for cooperation with Polonia and Poles abroad for 20152020', about 18-20 million Poles and people of Polish origin live outside Poland [8]. The strategic objectives of international educational programs in Poland are: to support the teaching of the Polish language, to strengthen Polish identity, to consolidate Polish communities abroad, to support their return to Poland [9]. In Poland, as in Russia, programs for attracting international students also attract potential highly qualified young people to the labour market.

Scholarship programs for studying in Poland are coordinated by NAWA (The Polish National Agency for Academic Exchange) [10]. The following programs are currently in operation: The gen. Anders Programme, Poland My First Choice Programme, Exchange programme for students and scientists with 26 countries, POLONISTA - scholarship and fellowship programme, The Banach Scholarship Programme (this programme is merged with Lukasiewicz Scholarship Programme into one programme for young people from developing countries). 
The primary source of international students in Russia remains the CIS countries. Their share in the 2018/2019 academic year was 51.6\% [4]. It is not only ethnic Russians who study in Russia, as it was thought some time ago. In recent years, large-scale migration flows in the world have also affected the post-Soviet space. Ethnic Kazakhs, Uzbeks, Tajiks and Turkmens also go to Russia and Poland for a diploma. If we compare the indicators of general and student migration to Russia, we can see an exciting trend. The volume of total migration shows a negative relationship with the US dollar exchange rate against the Russian ruble. When the US dollar strengthens and more Russian rubles are needed (the grey line in Figures 1 and 2), migration decreases. Figures 1 and 2 compare the dynamics of general and student migration from Kazakhstan and Tajikistan to Russia [11]. Student migration does not respond to changes in the exchange rate of the Russian ruble.

Five countries that supply the most significant number of students to Russian universities [4]: Kazakhstan (43318), China (36466), Turkmenistan (30090), Uzbekistan (18557), Tajikistan (17241). Five countries supplying the most significant number of students to Polish universities [5]: Ukraine (38473), Belarus (9739), India (2563), Turkey (1973), China (1609). 513 students from Lithuania study in universities in Poland, 465 in Russia. While there are about the same number of students from Latvia and Estonia in Russia, there are very few in Poland. The connection between Poland and Lithuania is associated with history; in both countries, most believers are Catholics.

Over the past 20-30 years, large ethnic and religious diasporas have attracted immigrants from the CIS countries. The role of the Russian language, the educational system, and the various ties that have developed over the long period of the Russian Empire and then the USSR are like the colonial ties that influence the direction of student migration [12]. Table 1 presents data on the number of international students in Russia and Poland from the five countries that supply the most significant number of students to the OECD countries [13].

Poland and Russia participate in the Erasmus+ program. Poland has the status of a program country status, which gives it more opportunities to attract funding and hold events on its territory. Russia has the status of a partner country status and can participate in a limited list of projects. The number of students from European countries is growing in Poland - from Spain, the Czech Republic, Germany and Norway. At the same time, the number of Swedes, Americans and Saudis has been declining for several years. More and more students come from Asia and Africa.

\subsection{Challenges for international students in Russia and Poland}

For international students in both countries, the main difficulties are associated with the need to know the local language. Only citizens of the CIS and the Balkans, as a rule, have a good command of Russian. Most students from other countries do not speak Russian before arriving in Russia and enrol in special courses during their first year. Even then, only $20 \%$ of them speak Russian at an intermediate level. This reduces the effectiveness of training. To prepare future applicants in 60 countries of the world, there are Russian language courses at the Russian Centres for Science and Culture [4]. Education in Russia and Poland is mainly conducted in the local language. The need to internationalise the education process requires changes. However, as a rule, Russian universities cannot provide foreign teachers with the same conditions as in developed countries. Therefore, some foreign teachers in Russia were students and received an academic degree here. Over the years, they have adapted to local conditions. The existing system of financing students from the federal budget is not specifically designed for international students and does not cover all the costs of studying in Russia [1]. Scholarship programs, which operate in several universities for international students, are much higher.

Table 1. Students of 5 main nationalities of international students enrolled in OECD countries

\begin{tabular}{|l|l|c|c|c|}
\hline N & \multicolumn{1}{|c|}{ Country of origin } & $\begin{array}{c}\text { OECD countries } \\
\text { in } 2019\end{array}$ & $\begin{array}{c}\text { Russia } \\
2018-2019 \text { academic } \\
\text { year }\end{array}$ & $\begin{array}{c}\text { Poland } \\
2018-2019 \text { academic } \\
\text { year }\end{array}$ \\
\hline 1 & China & 840870 & 36466 & 1609 \\
\hline 2 & India & 293,120 & 15166 & 2563 \\
\hline 3 & Viet Nam & 111,502 & 4749 & 554 \\
\hline 4 & Germany & 92,189 & 1400 & 1435 \\
\hline 5 & South Korea & 84,046 & 1743 & 106 \\
\hline
\end{tabular}

Compiled by the authors based on [4], [5], [13]. 
Grants for international students in Poland are determined within the framework of specific programs. Many international students would like to find work, even if they receive a Russian scholarship. However, it is easier for them to get a job in a foreign company or work unofficially. Good knowledge of the Russian language is required to communicate with authorities and organisations. The labour market requires qualified employees; not all foreign graduates of Russian universities can obtain a residence permit and get a job in Russia. Current legislation requires changes. The Russian authorities understand this and have simplified the procedure for extending students' visas and plan to simplify obtaining a residence permit for graduates and graduate students of universities. In Poland, there are also similar problems for international students: with legalisation, with accommodation, with opportunities to study the Polish language, and finding a job [14].

\subsection{Motives of international students when choosing universities in Russia and Poland}

According to the official websites of programs for promoting higher education abroad in Russia (studyinrussia.ru) and Poland (www.studyinpoland.pl), the main criterion for choosing universities in these countries is the high quality of education. For a more detailed study of this topic, consider our survey results conducted at RUDN University and publications.

To study the motivation of international students to learn in Russia in the fall semester of the 2020-2021 academic year, a survey was conducted among international students who study at RUDN University. The study was conducted according to a formalised questionnaire. 84 students from 18 countries took part in the survey. The distribution of students who participated in the survey by country: China $(16,7 \%)$, Tajikistan $(14,3 \%)$, Kazakhstan (10,7\%), Afghanistan and Uzbekistan (7,1\%), Bosnia and Herzegovina, the Congo Democratic Republic of El Salvador, Equatorial Guinea, Ethiopia, Greece, Iraq, Laos, Mongolia, Montenegro,
Paraguay, Vietnam - (3,6\% each), Comoros $(1,2 \%)$. According to this survey, most international students $(64.3 \%)$ want to find a job in their home country, $28.6 \%$ in Russia and $7.1 \%$ in third countries, usually in developed countries. The survey results are shown in Table 2. For comparison, Table 2 also shows the results of a survey conducted in 2012 with the participation of 2,000 international students [15].

Motives for foreign citizens to choose a specialisation in Russian universities, as a percentage: This speciality matches my abilities - 39.3 (survey 2012 - 37.1\%); This speciality is demanding and offers a competitive and high salary $39.3 \%$ (survey $2012-21.7 \%$ ); The high prestige of this speciality -28.6 (survey $2012-28.5 \%$ ).

Table 3 summarises the results of a study on the motivation of international students, which was carried out by Kubiciel-Lodzińska \& Ruszczak at the Opole University of Technology [16]. As can be seen from the survey results, the trend towards internalisation is becoming the main one for students. They strive to gain more knowledge and life experience to have a good job and prosperity.

\section{CONCLUSIONS}

The international higher education market is developing rapidly. Russia and Poland are actively developing their programs to attract and support international students. International students contribute to the economy by purchasing goods and paying for various services while living in the country of study. Since both countries are experiencing population decline, they are interested in attracting young, highly qualified people to the economy. First of all, Russia and Poland aim to attract students who speak the national languages of these countries and have connections with these countries. This simplifies the adaptation process and improves the quality of training. When choosing a country of study, economic motives and

Table 2. The main reason deciding to study in Russia, (more than one answer was allowed), in percent

\begin{tabular}{|l|c|c|}
\hline \multicolumn{1}{|c|}{ Results } & RUDN 2020 survey & 2012 survey [15] \\
\hline High quality of education in Russia & 35.7 & 62.1 \\
\hline An opportunity to get an education for free & 28.6 & 15.2 \\
\hline $\begin{array}{l}\text { There is no training on the specialty which I'm interested } \\
\text { in within my country's institutes of higher education }\end{array}$ & 7.1 & 5.4 \\
\hline $\begin{array}{l}\text { In my country the competition for admission to university } \\
\text { is more competitive }\end{array}$ & 28.6 & 3.5 \\
\hline I would like to study abroad & 39.3 & 16.1 \\
\hline I would like to study in Russia & 21.4 & 20.1 \\
\hline
\end{tabular}

Source: Analysis of the results obtained in the survey. 
Table 3. Reasons to take up study in Poland by foreign students (more than one answer was allowed)

\begin{tabular}{|l|c|c|c|}
\hline \multicolumn{1}{|c|}{ Results } & $\begin{array}{c}\text { Students from the } \\
\text { EU }\end{array}$ & $\begin{array}{c}\text { Students outside of } \\
\text { the EU }\end{array}$ & Total \\
\hline I have friends (relatives) in Poland & 42.9 & 5.3 & 7.5 \\
\hline I can speak Polish & 57.1 & 2.7 & 7.3 \\
\hline I was not able to take up study elsewhere & 0.0 & 2.7 & 14.6 \\
\hline $\begin{array}{l}\text { Poland is relatively close to my country of } \\
\text { origin }\end{array}$ & 0.0 & 16.0 & 39.0 \\
\hline I have a positive opinion about Poland & 42.9 & 38.7 & 48.8 \\
\hline $\begin{array}{l}\text { A degree awarded in Poland is } \\
\text { recognized by other EU countries }\end{array}$ & 28.6 & 65.3 & 12.2 \\
\hline $\begin{array}{l}\text { This is a head start into my professional } \\
\text { career }\end{array}$ & 0.0 & 53.3 & 25.6 \\
\hline I intend to settle in Poland in the future & 14.3 & & 12.0 \\
\hline $\begin{array}{l}\text { Studies in Poland will give an opportunity } \\
\text { to relocate to other EU countries }\end{array}$ & 0.0 & 28.0 & 20.7 \\
\hline Because of the high level of study & & & \\
\hline I have Polish roots & 42.9 & 9.3 & \\
\hline
\end{tabular}

Source: [16].

internationalisation play an essential role for young people.

\section{ACKNOWLEDGMENTS}

This paper has been supported by the RUDN University Strategic Academic Leadership Program.

\section{AUTHOR'S CONTRIBUTION}

Survey at the RUDN, A. Gusakov; all other work on the manuscript, both authors.

\section{REFERENCES}

[1] M. Kuzmenkov, A. Levashenko, Education services exports of Russia. Russian foreign economic journal 4 (2018) 39-50. Retrieved from: http://eng.rfej.ru/rvv/id?open\&page=F0070EB94

[2] A. Mihi-Ramirez, V. Kumpikaite, Economics reason of migration from students' point of view, Procedia - Social and Behavioral Sciences 109 (2014) 522-526.

[3] M. Chankseliani, Four rationales of $\mathrm{HE}$ internationalisation: Perspectives of UK universities on attracting students from former Soviet countries. Journal of Studies in International Education 22(1) (2017) 53-70.

DOI: https://doi.org/10.1177/1028315317725806
[4] A. Arefiev, Export of Russian educational services: Statistical Collection, Issue 10, Ministry of Science and Higher Education of the Russian Federation, M, Pushkin State Russian Language Institute, 2020.

[5] Higher education and its finances in 2020. Statistics Poland, 2020. Retrieved from: https://stat.gov.pl/en/topics/education/education/hi gher-education-and-its-finances-in-2020,2,14.html

[6] Resolution of the Government of the Russian Federation of December 18, 2020, N 2150. Retrieved from: http://ivo.garant.ru/\#/document/75091924/paragrap $\underline{\mathrm{h} / 1: 0}$

[7] The passport of the priority project "Development of the export potential of the Russian education system" was approved, 2017. Retrieved from: http://government.ru/news/28013/

[8] Rządowy program współpracy z Polonią i Polakami za granicą w latach 2015-2020, Ministry of Foreign Affairs of Poland, 2015. Retrieved from: https://www.gov.pl/web/dyplomacja/rzadowyprogram-wspolprac-z-polonia-i-polakami-zagranica-w-latach-2015-2020

[9] A. Stashkievich, The analysis of the Governmental Program for Cooperation with the Polish Diaspora for the years 2015-2020 in the scope of education policy of the Polish Government towards the Polish 
national minority in Ukraine, 2016. Retrieved from: https://periodicals.karazin.ua/philology/article/dow nload/6838/6329

[10] NAWA, The Polish National Agency for Academic Exchange, 2021. Retrieved from: https://nawa.gov.pl/en/nawa

[11] The Demographic Yearbook of Russia 2019. Retrieved from: https://gks.ru/bgd/regl/B19 16/Main.htm

[12] K.H. Lee, J.P. Tan, The international flow of third level lesser developed country students to developed countries: Determinants and implications. Higher Education 13(6) (1984) 687-707. DOI: https://doi.org/10. 2307/3446870

[13] OECD Education at a Glance Database. DOI: https://doi.org/10.1787/edu-data-en

[14] S. Das, A. Kochaniewicz, Non-EU students' potential challenges in Poland: the case of the City of Poznan, Trends Journal of Sciences Research 2(4) (2015) 117-120.

[15] A. Arefiev, F. Sheregi, international students in Russian higher education institutions. Moscow: Centre for Sociological Research, 2014. Retrieved from:

http://www.socioprognoz.ru/publ.html?id=365

[16] S. Kubiciel-Lodzińska, B. Ruszczak, The determinants of student migration to Poland based on the Opolskie Voivodeship study. International Migration 54(5) (2016) 162-174. DOI: https://doi.org/10.1111/imig.12257 